\title{
REKAYASA BAHAN KOMPOSIT HYBRID SANDWICH BERPENGUAT SERAT KENAF DAN SERAT GELAS DENGAN CORE KAYU PINUS
}

\author{
Agus Hariyanto \\ Teknik Mesin Universitas Muhammadiyah Surakarta \\ Jl. A.Yani Tromol Pos I Pabelan, Kartosura \\ email : agus_haryanto@ums.ac.id
}

\begin{abstract}
ABSTRAK
Tujuan penelitian ini adalah menyelidiki pengaruh ketebalan core melintang dan core membujur terhadap peningkatan kekuatan Impak komposit hibrid sandwich kombinasi serat kenaf dan serat gelas bermatrix Polyester dengan core kayu pinus. Mekanisme perpatahan diamati dengan photo makro.

Bahan utama penelitian adalah serat kenaf anyam dan serat E-Glass anyam, resin unsaturated polyester 157 BQTN, kayu pinus. Hardener yang digunakan adalah MEKPO dengan konsentrasi 1\%. Komposit dibuat dengan metode cetak tekan (press mold). Komposit hibrid sandwich tersusun terdiri dari dua skin (lamina komposit hibrid) dengan core ditengahnya. Lamina komposit hibrid sebagai skin terdiri dari beberapa lamina serat gelas anyam dan lamina serat kenaf anyam. Fraksi volume serat komposit hibrid sebagai skin adalah 30\%. Core yang digunakan adalah kayu pinus yang dipotong pada arah melintang dan arah membujur. Core yang digunakan ada 4 macam variasi ketebalan yaitu 5, 10, 15 dan 20 mm. Spesimen dan prosedur pengujian impak charpy mengacu pada standart ASTM D 5942. Penampang patahan dilakukan foto makro untuk mengidentifikasi pola kegagalannya.

Hasil penelitian ini menunjukkan bahwa penambahan ketebalan core melintang menurunkan energi serap dan kekuatan impak secara signifikan komposit hibrid sandwich. Seiring dengan peningkatan ketebalan core membujur juga menurunkan energi serap dan kekuatan impak secara signifikan pula. Namun, energi serap dan kekuatan impak pada core membujur meningkat secara signifikan dibandingkan dengan core melintang. Mekanisme patahan diawali oleh kegagalan komposit skin bagian tarik, core gagal geser, dan diakhiri oleh kegagalan skin sisi tekan. Pada bagian daerah batas core dan komposit skin menunjukkan adanya kegagalan delaminasi.
\end{abstract}

Kata Kunci: komposit hibrid sandwich, kekuatan impak, energi serap, mekanisme patahan.

\section{PENDAHULUAN}

Serat alam telah dicoba untuk menggeser pengunaan serat sintetis, seperti E-Glass, Kevlar-49, Carbon/ Graphite, Silicone Carbide, Aluminium Oxide, dan Boron. Walaupun tak sepenuhnya menggeser, namun penggunaan serat alam menggantikan serat sintesis adalah sebuah langkah bijak dalam menyelamatkan kelestarian lingkungan dari limbah yang dibuat dan keterbatasan sumber daya alam yang tidak 
dapat diperbaharui. Berbagai jenis tanaman serat tumbuh subur di Indonesia, seperti kenaf (hibiscus canabinus). Produksi serat kenaf dunia menduduki posisi mencapai 970.000 ton/tahun (Eichorn, 2001). Di Indonesia, serat kenaf tersebut biasanya hanya dipakai sebagai bahan karung goni sehingga nilai ekonominya rendah.

Ketersediaan kayu pinus (Pinus Merkusii) sangat berlimpah, namun nilai jualnya sangat murah (Siswamartana, 2002). Sifat ringan kayu ini selaras dengan filosofi rekayasa bahan komposit, yaitu menghasilkan disain ringan. Keberhasilan aplikasi kayu ini sebagai material core pada rekayasa bahan komposit diharapkan dapat menggantikan penggunaan bahan core sintetis impor dari luar negeri, seperti core polyurethane foam (PUF) dan core Divynil cell ( $P V C)$ (diabgroup).

Hal lain yang ironis adalah masuknya core kayu balsa yang diimpor dari Australia (diabgroup). Padahal, Indonesia sebagai negara tropis menghasilkan aneka kayu hasil hutan termasuk kayu balsa di Indonesia Timur dan kayu pinus di Pulau Jawa. Inovasi teknologi dengan memanfaatkan bahan alam merupakan langkah bijak menuju kemandirian bangsa yang bertumpu sumber daya alam lokal. Salah satu solusi kreatif terhadap banyaknya material impor yang masuk di Indonesia adalah memberdayakan material alam lokal yang bertumpu pada budaya riset yang berkelanjutan.

Berdasarkan uraian tersebut di atas, maka penggunaan serat kenaf dan kayu pinus sebagai bahan komposit sandwich merupakan solusi kreatif untuk mendukung perkembangan teknologi komposit yang ramah lingkungan. Penelitian ini bertujuan untuk menyelidiki pengaruh ketebalan core melintang dan core membujur terhadap peningkatan kekuatan bending komposit sandwich kombinasi serat kenaf dan serat gelas (hibrid) bermatrik Polyester dengan core kayu pinus dan mengidentifikasi Pola kegagalannnya.

\section{TINJAUAN PUSTAKA}

Yanuar, (2002), melakukan pengujian kekuatan bending dan impak pada komposit GFRP 3 layer. Dari hasil pengujian didapatkan bahwa komposit GFRP 3 layer dengan menggunakan serat E-Glass choped strand mats $300 \mathrm{gr} / \mathrm{m}^{2}$ mempunyai kekuatan bending $18 \%$ lebih besar dari pada dengan menggunakan serat E-Glass choped strand mats $450 \mathrm{gr} / \mathrm{m}^{2}$. Komposit GFRP 3 layer dengan menggunakan serat E-Glass choped strand mats $450 \mathrm{gr} / \mathrm{m}^{2}$ mempunyai kekuatan impak 46 \% lebih besar dari pada dengan menggunakan serat E-Glass choped strand mats $300 \mathrm{gr} / \mathrm{m}^{2}$. Pada pengujian bending, komposittersebutmengalami kegagalan pada bagian bawah spesimen. Hal ini menunjukkan bahwa kekuatan tarik material komposit GFRP lebih besar dibandingkan kekuatan tekannya.

Wahyanto dan Diharjo (2004) mensubstitusi penggunaan core PUF dan PVC dengan kayu sengon laut (KSL) yang dipotong melintang dan dikenai perlakuan borac 5\%, untuk mengeluarkan glukosa / sari pati kayu agar tahan terhadap serangan hama bubuk dan jamur. Warna kayu berubah dari putih kemerahan menjadi kuning kecoklatan. Pada kadar air ratarata 5,77\%, berat jenis kayu adalah $0,3 \mathrm{gr} / \mathrm{cm}^{3}$. Dengan dimensi yang hampir sama, komposit sandwich GFRP dengan core KSL memiliki kekuatan bending $108.87 \mathrm{MPa}$ atau $25.23 \%$ di atas kekuatan bending komposit GFRP sandwich dengan core PVC H 200. Namun, kekuatan impak komposit sandwich inti $P V C$ $H 200$ lebih tinggi karena core PVC bersifat lebih lentur sehingga lebih tahan terhadap beban impak. Usaha menggeser penggunaan serat gelas dengan serat alam, maka Febriyanto dan Diharjo (2004) meneliti kinerja bending dan impak komposit hibrid sandwich serat kenaf dan gelas dengan inti KSL. Kinerja bending komposit ini (100.44 MPa) lebih rendah 7.74\% di bawah kekuatan komposit sandwich GFRP inti KSL (108.87 MPa). Namun, ketahanan impak komposit hibrid sandwich tersebut lebih tinggi dibanding komposit GFRP sandwich inti KSL, yaitu $0.0628 \mathrm{~J} / \mathrm{mm}^{2}$ dan $0.058 \mathrm{~J} / \mathrm{mm}^{2}$. Salah satu faktor pendukung meningkatnya ketahanan impak ini adalah sifat alam serat kenaf yang lebih lentur/elastis. Pada panel komposit sandwich, penggunaan core KSL potongan membujur 
mampu meningkatkan kekuatan bending yang sangat tinggi, namun kekuatan impaknya hampir sama dengan potongan melintang. Kelemahan penggunaan core kayu potongan membujur adalah geometri panel dapat berubah (ngulet).

Hillger (1998) mengemukakan bahwa ada beberapa macam tipe kerusakan pada pengujian impak yang dapat dideteksi, seperti :retak dan delaminasi pada skin, debonding antara skin dan core serta kerusakan didalam core.

Luas kerusakan impak pada struktur sandwich dipengaruhi oleh material core dari tumpukan laminasi permukaan sandwich, ukuran, massa, kecepatan pendulum dan kemampuan dari komponen sandwich untuk menyerap beban kejut. Pada struktur sandwich dengan core foam delaminasi dapat dideteksi, yaitu daerah yang terimpak, yang berada di antara skin dan core (Gaedke, 2001).

\section{METODE PENELITIAN}

Bahan utama penelitian adalah serat $E$ glass anyam dengan density $2,42 \mathrm{gr} / \mathrm{cm}^{3}$, serat kenaf anyam dengan density $1,45 \mathrm{gr} / \mathrm{cm}^{3}$, core kayu pinus dengan density $0,45 \mathrm{gr} / \mathrm{cm}^{3}$., unsa-

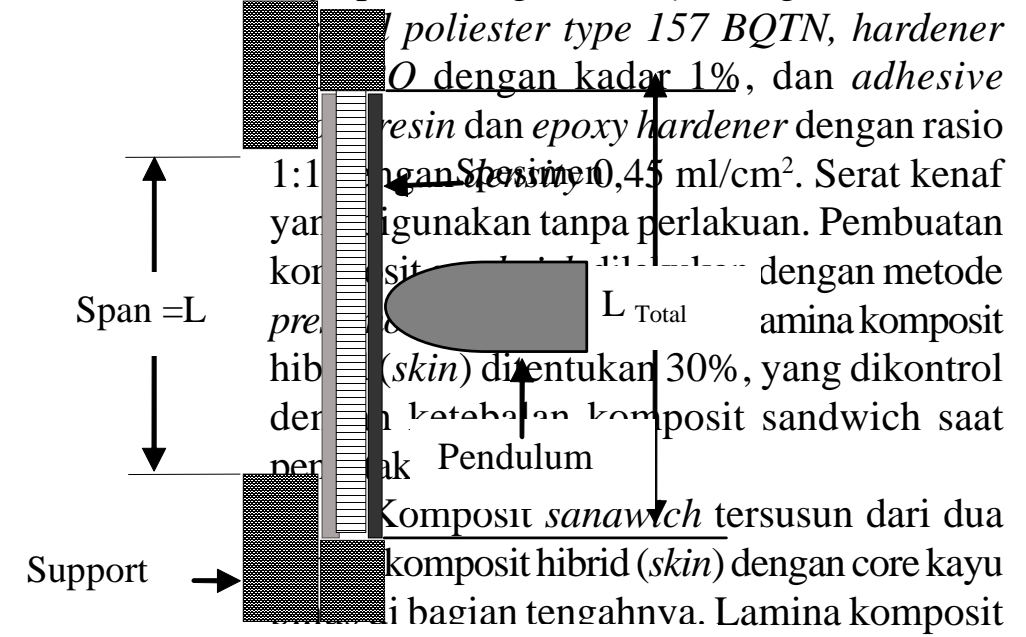
Gambar 2. Pemasangan spesimen lamina serat gelas uji impak ( Flat wise Impact) যnaf anyam. Serat a perlakuan. Core kayu pinus dibuat dengan pemotongan pada arah melintang (tegak lurus serat kayu) dan membujur (sejajar serat kayu). Ketebalan core divariasi 5, 10, 15, dan 20mm. Komposit sandwich yang sudah dicetak dipotong-potong menjadi spesimen uji.Pengujian dilakukan dengan flat impact method. Spesimen dan metode pengujiannya mengacu pada standar ASTM D 5942. Penampang patahan spesimen uji dilakukan foto makro.

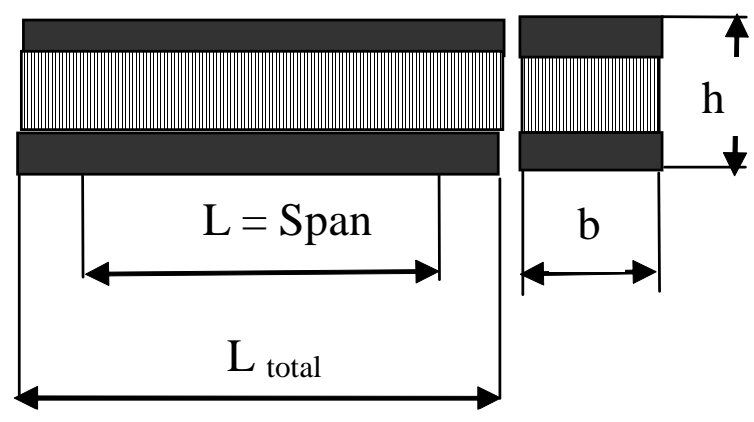

\section{Gambar 1. Spesimen Uji Impak Charpy}

\section{Gambar 2. Pemasangan Spesimen Uji Impak (Flat wise Impact)}

Persamaan yang digunakan dalam perhitungan sesuai standar ASTM D 5942 -96 sandwich sebagai berikut:

$$
\begin{aligned}
& \mathrm{W}=\mathrm{GxR}(\cos \beta-\cos \alpha) \\
& a_{c U}=\frac{W}{h \times b} \times 10^{3}=\frac{W}{h \times b}
\end{aligned}
$$


HASIL DAN PEMBAHASAN

Tabel 1. Energi serap uji komposit hibrid.

\begin{tabular}{|c|c|c|}
\hline \multirow[b]{2}{*}{$\begin{array}{l}\text { Tebal Core } \\
\text { (mm) }\end{array}$} & \multicolumn{2}{|c|}{ Energi Serap, Joule } \\
\hline & $\begin{array}{c}\text { Core } \\
\text { Melintang }\end{array}$ & $\begin{array}{c}\text { Core } \\
\text { Membujur }\end{array}$ \\
\hline 5 & 65 & 165,6 \\
\hline 10 & 56,4 & 141 \\
\hline 15 & 46,2 & 114,2 \\
\hline 20 & 34,2 & 83,4 \\
\hline
\end{tabular}

Tabel 2. Kekuatan impak komposit hibrid.

\begin{tabular}{|c|c|c|}
\hline \multirow{2}{*}{$\begin{array}{c}\text { Tebal Core } \\
\text { mm }\end{array}$} & \multicolumn{2}{|c|}{ Kekuatan Impak, J/mm $\mathbf{m}^{\mathbf{2}}$} \\
\cline { 2 - 3 } & $\begin{array}{c}\text { Core } \\
\text { Melintang }\end{array}$ & $\begin{array}{c}\text { Core } \\
\text { Membujur }\end{array}$ \\
\hline 5 & 0,274 & 0,695 \\
\hline 10 & 0,185 & 0,464 \\
\hline 15 & 0,12 & 0,298 \\
\hline 20 & 0,075 & 0,183 \\
\hline
\end{tabular}

Komposit hibrid sandwich yang diperkuat serat kenaf anyam dan serat E-glass anyam menyerap energi impak lebih rendah, seperti ditunjukkan pada tabel 1 . Pada Hal yang sama juga terjadi pada perhitungan kekuatan impak pada tabel 2.

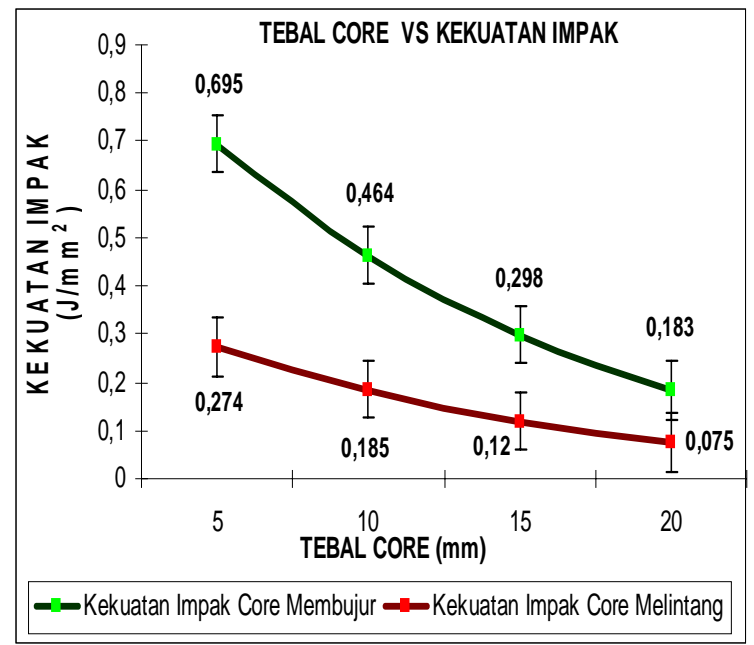

\section{Gambar 4. Kekuatan Impak Komposit Sandwich.}

Dari pengujian impak Charpy, diperoleh kemampuan energi serap komposit hibrid sandwich core melintang dan dengan core membujur seperti pada gambar 3. Berdasarkan gambar tersebut, energi serap menurun seiring dengan penambahan ketebalan core. Dengan demikian, penambahan bagian inti struktur sandwich menunjukkan secara signifikan penurunan kemampuan menyerap energi impak. Sifat material yang lebih lunak (kayu pinus) dan penambahan ketebalan menyebabkan memiliki kemampuan menyerap energi yang lebih rendah.

Selain itu, efek core melintang pada serat kenaf anyam dan serat E-glass anyam menurunkan energi serap hasil uji impak. Hal ini dapat disebabkan oleh perubahan perilaku posisi serat kayu pinus pada komposit hibrid sandwich menjadi lebih getas.

Bila ditinjau dari segi kekuatan impak, penebalan core menurunkan kekuatan impak komposit hibrid sandwich. Kekuatan impak komposit hibrid sandwich yang diperkuat serat kenaf anyam dan serat E-glass anyam dengan core membujur memiliki harga yang lebih tinggi. Dengan demikian, sifat keuletan bahan ini dapat dikatakan lebih baik.

\section{Gambar 3. Energi Serap Uji Impak Komposit Sandwich.}




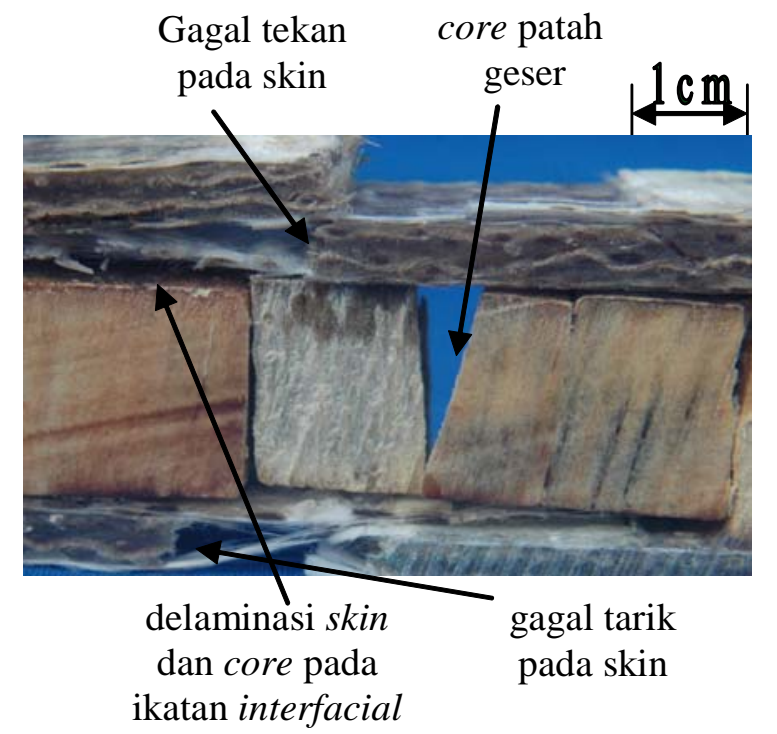

\section{Gambar 5. Permukaan Patah Core Melintang}

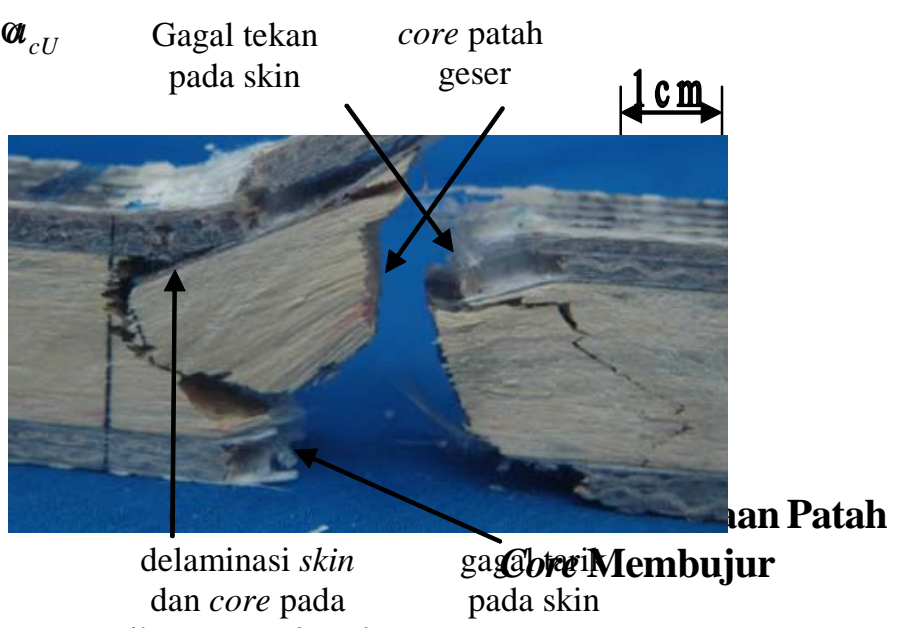

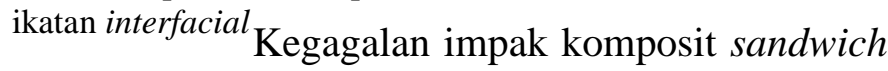

Gambar 6. Permukaan patah core ${ }^{\prime \cdots}$ at dalam gambar 5. membujur wali dengan retakan renderita tegangan tarik. Kemudian, beban impak tersebut didistribusikan pada core sehingga menyebabkan core mengalami kegagalan. Skin yang semula menderita beban tekan akhirnya mengalami kegagalan seiring dengan gagalnya core.

Dari spesimen uji mengalami kegagalan tarik pada komposit skin atas, patah geser core dan kegagalan tekan pada kedua skin. Mekanisme patahan terjadi karena kegagalan komposit hibrid sandwich akibat beban impak berawal dari skin komposit sisi belakang dan dilanjutkan dengan kegagalan core, delaminasi skin dan core pada ikatan interfacial.

\section{KESIMPULAN}

Berdasarkan data hasil penelitian tersebut maka dapat disimpulkan sebagai berikut:

1. Efek penambahan ketebalan core melintang menurunkan energi serap dan kekuatan impak secara signifikan komposit hibrid sandwich. Seiring dengan peningkatan ketebalan core membujur juga menurunkan energi serap dan kekuatan impak secara signifikan.

2. Namun, energi serap dan kekuatan impak pada core membujur meningkat secara signifikan dibandingkan dengan core melintang.

3. Mekanisme patahan akibat beban impak diawali oleh kegagalan komposit skin bagian tarik, core gagal geser, dan diakhiri oleh kegagalan skin sisi tekan. Pada bagian daerah batas core dan komposit skin menunjukkan adanya kegagalan delaminasi pada ikatan interfacial..

\section{NOTASI PERSAMAAN}

$$
\begin{aligned}
\mathrm{W} & =\text { Energi patah/serap }(\mathrm{J}) \\
\mathrm{G} & =\text { Berat pendulum }(\mathrm{N}) \\
\mathrm{R} & =\text { Jarak pendulum ke pusat rotasi }(\mathrm{m}) \\
\beta & =\text { Sudut pendulum setelah menabrak } \\
& \text { benda uji }\left(^{\circ}\right) \\
= & \text { Sudut pendulum tanpa benda uji }\left(^{\circ}\right) \\
= & \operatorname{Kekuatan} \text { impak }\left(\mathrm{J} / \mathrm{mm}^{2}\right) \\
\mathrm{h} & =\text { Tebal specimen }(\mathrm{mm}) \\
\mathrm{b} & =\operatorname{Lebar} \operatorname{specimen}(\mathrm{mm})
\end{aligned}
$$




\section{DAFTAR PUSTAKA}

Annual Book of Standards, Section 8, D 5942-96, "Standard Test Methods forDetermining Charpy Impact Strength of Plastics" ”, ASTM, 1996.

Anonim, 2001,Technical data Sheet, PT Justus Sakti Raya Corporation, Jakarta.

Anonim, www.diabgroup.com, DIAB manufactures and markets products and services based on advanced polymer and composite technologies, Head OfficeDIAB AB Box 201S31222 LAHOLM Sweden.

Eichorn, S.J., Zafeiropoulus, C.A.B.N., Ansel, L.Y.M.M.P., Entwistle, K.M., Escamilla, P.J.H.F.G.C., Groom,L, Hill, M.H.C., Rials, T.G. and Wild, P.M., 2001, Review Current International Research into Cellulosic Fibers and Composites, Journal of Materials Science, Vol. 36, pp. 2107-2131

Febrianto, B. dan Diharjo, K., 2004, Kekuatan Bending Dan Impak Komposit Hibrid Sandwich Kombinasi Serat Karung Goni Dan Serat Gelas Polyester Dengan Core Kayu Sengon Laut, Skripsi, UNS, Surakarta

Gaedke, M, 2001, Impact Behavior and Residual Strength of Sandwich Structual Elements Under Static and Fatique Loading, American Institute of Aeronautics and Astronautics, Germany.

Hillger, 2003, Inspection of CFRP and GFRP Sandwich Components, Wilhelm Raabe Weg 13, D-38110 Braunschweig.

Siswamartana,. 2002.”Hutan Pinus dan Hasil Air” Cepu: Pusat Pengembangan Sumber Daya Hutan Perhutani.

Wahyanto, B. dan Diharjo, K., 2004, Karakterisasi Uji Bending Dan Impak Komposit Sandwich GRFP Dengan Core Kayu Sengon Laut, Skripsi, UNS, Surakarta

Yanuar, D, 2002, Pengaruh Berat Serat Chooped Strand Terhadap Kekuatan Bending, Impak dan Tarik Komposit GFRP, UNS, Surakarta. 